\title{
Jan Szumski
}

\section{Źródła do historii Polaków w Rosji sowieckiej i ZSRR w dwudziestoleciu międzywojennym w zbiorach proweniencji sowieckiej w Archiwum Instytutu Hoovera}

\begin{abstract}
Abstrakt: Przedmiotem artykułu jest analiza zbiorów posowieckich w zasobach Archiwum Instytutu Hoovera przeprowadzona pod kątem polskiej problematyki. W prezentowanym ujęciu dzieje narodu polskiego w XX w. nie ograniczają się do historii państwa polskiego i osób będących obywatelami polskimi. Możliwości badawcze oferowane przez amerykańską placówkę pozwalają na rozszerzenie obszaru badań sowietologicznych w oparciu o trudno dostępne $\mathrm{w}$ miejscu stałego przechowywania materiały proweniencji sowieckiej.
\end{abstract}

Słowa kluczowe: Archiwum Hoovera, sowiecka polityka narodowościowa, polska mniejszość, ZSRR.

Abstract: The article presents an analysis of the post-Soviet collections preserved in the Hoover Archives conducted through the lens of Polish issues. In the proposed approach, the history of the Polish nation in the twentieth century is not limited to the history of the Polish state and Polish citizens. The research possibilities offered by the Hoover Institution make it possible to broaden the field of research into the Soviet issues based on materials of the Soviet provenance difficult to access in their place of permanent storage.

Keyw or ds: Hoover Archive, Soviet national policy, Polish minority, USSR. 
Instytut Wojny, Rewolucji i Pokoju im. Hoovera przy Uniwersytecie Stanforda od lat jest znany i odwiedzany przez polskich badaczy. Wedle niektórych danych archiwum gromadzi ok. $50 \mathrm{mln}$ jednostek archiwalnych (ok. 6500 zbiorów archiwalnych albo $40 \mathrm{~km}$ półek), z czego aż $25 \%$ to dokumenty w językach słowiańskich ${ }^{1}$. Pewien kłopot stanowią stosowane w różnych krajach sposoby obliczenia zasobów archiwum oraz zasady opracowania dokumentów. Jak wiadomo, w polskich archiwach wykorzystuje się obliczenia w metrach bieżących, a więc liczona jest liczba akt, która mieści się na jednym m.b. półki. W Rosji i większości krajów postsowieckich zasoby archiwum mierzy się w jednostkach archiwalnych (единица хранения).

W Archiwum Hoovera zgromadzone dokumenty łączy się w jednostki archiwalne w ramach zespołów (collections) i spuścizn (papers). Jednostkę tę określa często pojemność pudła (box), a numery pudeł pełnią rolę sygnatur. Mniejszą podjednostką są foldery (folders), które również mają swoje numery. Zaznaczyć warto, że w odróżnieniu od akt przechowywanych w archiwach w Europie Wschodniej akta w amerykańskich archiwach nie sa paginowane.

Pokaźna część zasobów Archiwum Hoovera stanowią zbiory w języku rosyjskim, które jednak często dotyczą Polski i Polaków. Z kolei polskie zbiory tej prywatnej instytucji nie przewyższają liczebnie zbiorów rosyjskich, ale sa bodajże jedną z najbogatszych i najbardziej wartościowych kolekcji zagranicznych dotyczących najnowszej historii Polski². Przechowuje się tu zarówno materiały wytworzone przez polskie urzędy i organizacje w kraju i na emigracji z okresu II Rzeczypospolitej, jak i zbiory o charakterze prywatnym.

Przybliżanie po raz kolejny bogatych zasobów polskiej proweniencji w Archiwum Hoovera, które na dodatek były już częściowo przekazywane do Polski w formie mikrofilmów, jak chociażby akta Ministerstwa Informacji i Dokumentacji Rządu RP na uchodźstwie, Ambasady RP w Moskwie oraz placówek dyplomatycznych i konsularnych, nie wnosiłoby nic nowego do tematu. Zarys dziejów archiwum oraz proces gromadzenia i uzupełniania polskich archiwaliów poruszał w swoich publikacjach opiekun Kolekcji Europejskiej Instytutu Hoovera, archiwista Maciej Siekierski ${ }^{3}$. Scharakteryzował on również

${ }^{1}$ Zob. B. Winid, Wspótczesne archiwalia polskie i rosyjskie w zbiorach Instytutu Hoovera [tłum. z j. ang. E. Rosowska], „Archeion” 1995, t. XCV, s. 243-245. Zob. też: Е. Даниельсон, Архивьь русских элигрантов в Гуверовскол институте, „Вестник архивиста” 2001, № 1, с. 202-211.

2 Zob. chociażby przewodnik po polskich zbiorach: W. Stępniak, Archiwalia polskie w zbiorach Instytutu Hoovera Uniwersytetu Stanforda, Warszawa 1997. Informacje o polonikach w zbiorach paryskiej Ochrany zob. L. Zasztowt, M. Siekierski, Dwie rosyjskie kolekcje w zbiorach Archiwum Instytutu Hoovera Uniwersytetu Stanforda, „Przegląd Wschodni” 2000, t. VII, z. 1 (25), s. 159-182. Dokumentację autorstwa Jana Karskiego z lat 1945-1949, przechowywaną w Instytucie Hoovera zob. N. Siekierski, Jan Karski i Instytut Hoovera, „Archeion” 2011, t. CXII, s. 153-160.

${ }^{3}$ M. Siekierski, Zarys historii polskich zbiorów Biblioteki i Archiwum Instytutu Hoovera $w$ Kalifornii, „Z Badań nad Książką i Księgozbiorami Historycznymi” 2017, tom specjalny, s. $557-566$. 
dokumentację dotyczącą martyrologii Polaków w Związku Sowieckim po wkroczeniu wojsk sowieckich do Polski 17 IX 1939 r. ${ }^{4}$ Losy Polaków w ZSRR po sowieckiej agresji na Polskę badał na początku lat dziewięćdziesiątych na podstawie trzech zespołów archiwalnych polskiej proweniencji stypendysta Hoover Institution, współpracownik Archiwum Wschodniego, Mirosław Filipiak ${ }^{5}$.

Inaczej wygląda sprawa zbiorów posowieckich, które, jak się wydaje, sa mało zbadane pod kątem problematyki polskiej. Na potrzebę przeprowadzenia w tych materiałach specjalistycznej kwerendy wskazywał Władysław Stępniak, wieloletni pracownik, a następnie kierownik Naczelnej Dyrekcji Archiwów Państwowych, który przeprowadził wstępne kwerendy w zespołach i kolekcjach rosyjskich Archiwum Hoovera, poszukując materiałów dotyczących historii Polski i Polaków ${ }^{6}$.

Zamierzam w ramach niniejszego artykułu skupić się na analizie dokumentacji dotyczącej Polaków w Rosji sowieckiej i ZSRR w dwudziestoleciu międzywojennym i znajdującej się w zespołach „niepolskich” proweniencji sowieckiej w Archiwum Hoovera (AH). Dodatkowo spróbuję odpowiedzieć na pytanie: jakich instytucji sowieckich odpowiedzialnych za politykę narodowościową akta są obecnie dostępne w AH oraz naświetlę skomplikowany proces pozyskiwania tych dokumentów przez stronę amerykańską na tle zmian zachodzacych w Rosji w latach dziewięćdziesiątych. Główną tezą badawcza jest twierdzenie, że zasoby $\mathrm{AH}$ w Kalifornii, a szczególnie akta proweniencji sowieckiej, stanowią bogate i mało zbadane przez sowietologów źródło wiedzy na temat losów Polaków w Rosji sowieckiej i ZSRR w okresie po przewrocie bolszewickim 1917 r. do momentu wybuchu II wojny światowej.

Badań sowieckiej polityki narodowościowej nie można prowadzić w oderwaniu od polityki partii bolszewików. Zakres przedmiotowy oraz przestrzenny spraw, którymi zajmował się Komitet Centralny Rosyjskiej Komunistycznej Partii (bolszewików) [KC RKP(b)], a od 1925 r. Wszechzwiązkowej Komunistycznej Partii (bolszewików) [WKP(b)], obejmował również sprawy polskie, określane w dokumentacji sowieckiej jako польский вопрос. Wyrażenie „kwestia polska” zmieniło w czasach sowieckich swoją semantykę. W XIX i na początku XX w. używano go bowiem w odmiennym znaczeniu ${ }^{7}$. W pewnym

${ }^{4}$ Idem, Hoover Institution's Polish Collections: An Overview and a Survey of Selected Materials on Polish Soviet Relations, „Polish Review” 1988, t. XXXIII, nr 3, s. 325-341.

${ }^{5}$ Por. Archiwalia Ambasady RP w Moskwie-Kujbyszewie (1941-1943) i Ministerstwa Informacji i Dokumentacji (1939-1945) w zbiorach Instytutu Hoovera Uniwersytetu Stanforda, oprac. M. Filipiak, Warszawa 2002.

${ }^{6}$ Szerzej na ten temat zob. W. Stępniak, Możliwości badawcze historyków polskich na Uniwersytecie Stanforda. Polonika w zbiorach Hoover Institution Archives, „Archeion” 1997, t. XCIVII, s. 112-116.

${ }^{7}$ Por. H. Głębocki, Fatalna sprawa. Kwestia polska w rosyjskiej myśli politycznej (1856-1866), Kraków 2000; Л. Горизонтов, Парадоксы илперской политики. Поляки в России и русские у Польше, Москва 1999. 
uproszczeniu można powiedzieć, że wówczas rozumiano ten problem jako postawienie sprawy polskiej na arenie międzynarodowej w celu odbudowania państwa. Właśnie w ten sposób „kwestię polską przedstawiał Roman Dmowski w swoim geopolitycznym opracowaniu Niemcy, Rosja i kwestia polska, wydanym po raz pierwszy w 1908 r. i przetłumaczonym na wiele języków.

Lata dwudzieste i trzydzieste ubiegłego wieku były okresem burzliwych przemian i eksperymentów narodowościowych realizowanych w ówczesnym Związku Sowieckim z udziałem ok. milionowej rzeszy Polaków. Zapoczątkowana we wczesnych latach dwudziestych polityka korienizacji, a więc zwiększania udziału miejscowej, rdzennej (rdzeń, czyli корень) ludności w aparacie państwowym i partyjnym, promowania narodowych języków i kultur, miała na celu zwiększenie wpływów i popularności partii komunistycznej wśród nierosyjskich narodów Rosji sowieckiej, a następnie ZSRR. Obok tworzenia republik narodowościowych (związkowych) w Azji Środkowej, na Kaukazie i na terytorium europejskiej części byłego Imperium Rosyjskiego, realizowano politykę tworzenia lokalnych autonomii dla mniejszości, których państwa narodowe pozostawały poza granicami ZSRR.

Polacy równolegle z Niemcami stanowili najliczniejszą i zarazem szczególna grupę wśród „narodów ZSRR”, określaną jako „zachodnie” albo „eksterytorialne” mniejszości narodowe. Polacy lub komuniści polskiego pochodzenia wchodzili w skład najwyższych władz partyjnych, państwowych, wojskowych oraz gospodarczych i tworzyli na początku lat dwudziestych potencjał nowej Rosji sowieckiej na płaszczyźnie polityki (w bolszewickiej partii i rządzie) i gospodarki (inżynierowie, kolejarze, elita robotnicza Zakładów Putiłowskich w Piotrogradzie). Zgodnie z ówczesną nomenklatura zaliczani byli do grupy „mniejszości narodowych znajdujących się na wyższym poziomie rozwoju”.

Osobna kwestię stanowią sowieckie projekty narodowościowe - Polski Rejon Narodowy im. Feliksa Dzierżyńskiego (Dzierżyńszczyzna) na terytorium BSRR i Polski Rejon Narodowy im. Juliana Marchlewskiego (Marchlewszczyzna) na sowieckiej Ukrainie, realizowane od drugiej połowy lat dwudziestych. W ramach autonomii tworzono polskie rady wiejskie, przedszkola, szkoły, technika pedagogiczne, domy dziecka, sady, instytucje kultury i oświaty. Na sowieckiej Białorusi język polski, obok białoruskiego, rosyjskiego i jidysz, uzyskał status języka państwowego.

Owe eksperymenty znalazły swój krwawy finał w „Operacji polskiej NKWD 1937 r.”, będącej zarazem jednym z elementów tzw. Wielkiego Terroru. Jak wykazała wstępna kwerenda przeprowadzona przez piszącego niniejsze słowa ${ }^{8}$,

\footnotetext{
${ }^{8}$ Kwerenda ta odbyła się w ramach stypendium przyznanego przez dyrektora Archiwum Hoovera, Erica Wakina. Mogłem ją przeprowadzić na przełomie marca i kwietnia 2018 r. Szczególne podziękowania kieruję pod adresem Pani Lory Soroki, Ireny Czernichowskiej, dr. Macieja Siekierskiego, Sarah Patton oraz innych pracowników, którzy ciagle służyli mi radą i pomocą w czytelni.
} 
w zbiorach proweniencji sowieckiej znajduja się bogate materiały na temat „kwestii polskiej” w ZSRR. Warto zatem zadać pytanie, jak sowieckie zbiory trafiły do magazynów Archiwum Hoovera. Aby na nie odpowiedzieć, musimy się cofnąć do schyłkowego okresu istnienia ZSRR, a dokładnie do roku 1991.

W tym czasie w Rosji dokonywała się „rewolucja archiwalna”, by użyć tu określenia spopularyzowanego przez Rudolfa Pichoję, rosyjskiego historyka i archiwistę, kierownika Państwowej Służby Archiwalnej Rosji w latach 1990-1996. Polegała ona przede wszystkim na „tworzeniu ustawodawstwa regulującego działalność pionu archiwalnego, niezależnie od przynależności resortowej, zapewnieniu równych praw dla obywateli do dostępu do zasobów archiwalnych, przekazaniu materiałów archiwów KPZR oraz nawiązywaniu współpracy międzynarodowej w ramach projektów”. Jednym z najbardziej spektakularnych projektów międzynarodowych realizowanych przez resort Pichoi była współpraca z Instytutem Wojny, Rewolucji i Pokoju im. Hoovera w latach 1992-1996 ${ }^{10}$.

Pierwsze rozmowy na temat ewentualnej kooperacji prowadzono w maju 1991 r. w schyłkowym okresie istnienia ZSRR i narastajacego konfliktu pomiędzy przewodniczącym Rady Najwyższej RSFSR Borysem Jelcynem a prezydentem ZSRR Michaiłem Gorbaczowem. Wówczas Pichoja, który zajmował stanowisko kierownika Komitetu ds. Archiwów przy Radzie Ministrów RSFRR $^{11}$, podpisał pierwsze porozumienia o współpracy z brytyjska grupa wydawniczą Chadwyck-Healey Ltd z siedzibą w Cambridge, która specjalizowała się w kopiowaniu i dystrybucji materiałów źródłowych dla nauk społecznych i humanistycznych. Następnie w USA w Kalifornii 26 V 1991 r. doszło do zawarcia umowy ramowej o współpracy z Instytutem Hoovera ${ }^{12}$.

Katalizatorem przyspieszającym współpracę był pucz sierpniowy w Moskwie (19-21 VIII 1991 r.), w którego wyniku Komitet ds. Archiwów przy Rządzie Federacji Rosyjskiej ${ }^{13}$ przeją posowieckie archiwa partyjne. Na przełomie 1991 i 1992 r. do Moskwy przybywały tłumy „pielgrzymów archiwalnych” w nadziei na dostęp do ukrywanych do niedawna partyjnych dokumentów oraz dokumentacji służb specjalnych. Padały różne oferty, nieraz bardzo atrakcyjne finansowo, obwarowane jednak jednym warunkiem - wyłącznym prawem dostępu i wykorzystania archiwaliów.

${ }_{9}$ Р.Г. Пихоя, Записки археографба, Москва 2016, с. 238-274.

${ }^{10} \mathrm{O}$ kontaktach Instytutu Hoovera z Rosarchiwem wiadomo było w Polsce m.in. za sprawa informowania o przebiegu projektu na łamach „Archeionu”. Zob. chociażby: B. Winid, op. cit., s. 243-245.

11 Комитет по делам архивов при Совете Министров РСФСР (Роскомархив). Zob. История Росархива, http://archives.ru/rosarhiv/history.shtml (dostęp: 16 X 2018).

12 В.П. Козлов, Российские архивь:: проблель доступа и использования, „Делопроизводство" 2012, № 1, с. 7-8.

${ }^{13}$ Комитет по делам архивов при Правительстве Российской Федерации (Роскомархив) funkcjonował w okresie od września 1991 do grudnia 1992 r. Zob. История Росархива... 
Pichoja w swoich wspomnieniach pisał o bezprecedensowej presji wywieranej na niego przez różne środowiska. Rozważano możliwość publikacji dokumentów we współpracy z Włodzimierzem Bukowskim, słynnym dysydentem rosyjskim, pracującym wówczas jako reprezentant Jelcyna w sprawie o niekonstytucyjność Komunistycznej Partii Związku Radzieckiego (KPZR), toczonej przed Trybunałem Konstytucyjnym Federacji Rosyjskiej, o czym mowa będzie dalej, oraz dyrektorem Biblioteki Kongresu USA, Jamesem Hadleyem Billingtonem. W końcu wybrano wspomniany już Instytut Hoovera. Pichoja tłumaczył, że za dokonaniem takiego wyboru przemawiały liczne względy: możliwość zachowania tajemnicy państwowej przy jednoczesnym udostępnianiu dokumentów, kopiowanie dokumentów odbywało się na zasadach parytetu (strona rosyjska uzyskiwała taką samą liczbę kopii dokumentów Rossica), strona amerykańska miała zapewnić odpowiedni sprzęt do kopiowania i pokrywała wszystkie koszty ${ }^{14}$.

Kolejne porozumienie, podpisane na wiosnę 1992 r., zakładało równolegle mikrofilmowanie dokumentów przechowywanych w Archiwum Hoovera, zaś po stronie rosyjskiej - w trzech archiwach federalnych: w GARF ${ }^{15}$, RGASPI $^{16}$ oraz RGANI ${ }^{17}$. W tym samym czasie zawarto również porozumienie dotyczące kopiowania ksiag metrykalnych dla Towarzystwa Genealogicznego w stanie Utah w USA (The Genealogical Society of Utah). W 1996 r. współpraca ze stroną amerykańską została przerwana na wniosek strony rosyjskiej.

Konflikt, który wybuchł na jesieni 1995 r. pomiędzy Rudolfem Pichoja a Władimirem Kozłowem, ówczesnym członkiem Kolegium Rosarchiwu i jego zwolennikami, doprowadził do zerwania umowy ze stroną amerykańską. Wielokrotnie wspominany już Pichoja jako powód do rezygnacji ze współpracy

${ }^{14}$ Р. Пихоя, ор. cit., с. 291-292. Więcej szczegółów na temat przebiegu rozmów i realizacji projektu podaje Bernard Butcher. Zob. idem, Cracking the Kremlin Files, „Hoover Digest” 1999, nr 4, https://www.hoover.org/research/cracking-kremlin-files (dostęp: 16 X 2018).

15 GARF (Государственный архив Российской Федерации - Państwowe Archiwum Federacji Rosyjskiej) powołano w kwietniu 1992 r. Archiwum gromadzi materiały wyższych organów władzy państwowej i administracji Rosji i ZSRR.

${ }^{16}$ RGASPI (Российский государственный архив социально-политической истории - Rosyjskie Państwowe Archiwum Historii Społeczno-Politycznej) powołano do życia w marcu 1999 r. w wyniku fuzji dwóch archiwów. Od 1991 r. archiwum funkcjonowało pod nazwą Российский центр хранения и изучения документов новейшей истории (РЦХИДНИ) - Rosyjskie Centrum Przechowywania i Badań Dokumentów Historii Najnowszej (RCPBDHN). Po połączeniu z Centrum Przechowywania Dokumentów Organizacji Młodzieżowych (CPDOM) - Центр хранения документов молодежных организаций (ЦХДМО) utworzono RGASPI. Archiwum wywodzi się w linii prostej z Centralnego Archiwum Partyjnego Instytutu Marksizmu-Leninizmu przy KC KPZR i Centralnego Archiwum Komsomołu.

17 RGANI (Российский государственный архив новейшей истории - Rosyjskie Państwowe Archiwum Historii Najnowszej) powołano w październiku 1991 r. jako Centrum Przechowywania Współczesnej Dokumentacji - Центр хранения современной документации (ЦХСД). W marcu 1999 r. nazwę archiwum zmieniono na RGANI. W archiwum przechowane są głównie dokumenty KPZR za okres od 1952 do sierpnia 1991 r. 
z Amerykanami podał, że w pewnym sensie na dalszy los projektu wpływ miały wybory prezydenta Rosji w 1996 r., gdy Jelcyn zwyciężył w drugiej turze z kandydatem komunistów, Giennadijem Ziuganowem.

Jak twierdził były szef Rosarchiwu, jeden z obszarów krytyki dokonywanej przez politycznych oponentów Jelcyna stanowiła jego nazbyt liberalna polityka archiwalna - odtajnianie i publikacje dokumentów oraz kontakty międzynarodowe. Krytyka oscylowała między bardzo ostrożnymi sformułowaniami typu „społeczeństwo nie jest przygotowane na odbiór takiej informacji” a bezpośrednimi oskarżeniami typu „oddaliśmy wszystko za granicę"18 czy „wyprzedajemy nasze dziedzictwo narodowe”19. Kierownik Rosarchiwu złożył rezygnację na ręce swojego bezpośredniego przełożonego, prezydenta Jelcyna, licząc na polityczne wsparcie, którego jednak nie otrzymał. Rezygnacja została przyjęta w styczniu 1996 r., a stanowisko szefa Rosarchiwu obją Kozłow.

W latach 1992-1996 wykonano kopie 1,5 mln klatek mikrofilmów dokumentów, a w kolejnych latach dodatkowo ok. 3 mln klatek w ramach osobnego projektu dotyczącego historii GUłagu z zasobów GARF. Umowa z GARF została podpisana w czerwcu 1998 r. i oficjalnie zakończyła się w czerwcu 2004 r. Wedle szacunków strony amerykańskiej Instytut Hoovera pozyskał w tym czasie łącznie 11676 rolek mikrofilmów (reels), każda o zawartości od 500 do 850 klatek $^{20}$.

Strona rosyjska, oprócz zdobycia kopii kilku milionów dokumentów z Archiwum Hoovera dotyczacych rosyjskiej emigracji ${ }^{21}$, zarobiła na tej transakcji ok. 3 mln USD ${ }^{22}$. Adwersarz Pichoi w sporze o współpracę z Amerykanami, Kozłow podał inną kwotę uzyskaną w latach 1992-2002 ze sprzedaży mikrofilmów - 4 mln 742 tys. USD, z czego ok. 1 mln 280 tys. USD (po odprowadzeniu podatków) zasiliło konta trzech rosyjskich archiwów ${ }^{23}$. W skali państwa rosyjskiego i w warunkach grabieży majątku narodowego Rosji dokonywanego na początku lat dziewięćdziesiątych ubiegłego wieku była to

${ }^{18}$ Chodziło o przekazanie w latach 1993-1994 Francji ok. 1 mln dokumentów archiwalnych z zasobów tzw. Specjalnego Archiwum (Особый архив), zdobytych jako trofea przez Armię Czerwona, m.in. materiałów francuskiego kontrwywiadu (Direction Générale à la Sûreté Nationale, Paris) i in. Realizacja tego projektu wywołała protest części środowisk politycznych w rosyjskim parlamencie. Przez kolejne trzy lata wstrzymano przekazywanie materiałów stronie francuskiej, aż w listopadzie 1997 r. rząd FR podjął decyzję o przekazaniu ostatniej puli dokumentów stronie francuskiej. Więcej zob. P. Libera, Restytucja archiwaliów francuskich z Archiwum Specjalnego w Moskwie, „Archeion” 2006, t. CIX, s. 131-157.

19 Р.Г. Пихоя, ор. cit., с. 318.

${ }^{20}$ Cyt. za: Twelwe Years of Cooperation with Russian Archives, http://media.hoover.org/sites/ default/files/documents/decade2.pdf (dostęp: 23 X 2018).

${ }^{21}$ Sa to m.in. dokumenty rosyjskich misji dyplomatycznych (Ambasada Rosji w Paryżu), rosyjskiej Ochranki (Oddział Paryski), prywatne zbiory liderów „białego” ruchu (generałów Nikołaja Judenicza i Piotra Wrangla) czy bogate materiały dotyczące rodziny ostatniego cara Rosji Nikołaja II Romanowa.

22 Р.Г. Пихоя, ор. cit., с. 292.

${ }^{23}$ В.П. Козлов, ор. cit., с. 12. 
kwota znikoma ${ }^{24}$. Niemniej jednak w sytuacji kryzysu i zapaści gospodarczej w Rosji w tym czasie taki zastrzyk gotówki pozwolił nie tylko na przetrwanie załogom wymienionych wyżej instytucji, ale również innych archiwów.

Abstrahujac od strony finansowej transakcji oraz towarzyszacych jej oskarżeń o „zdradę” i „wyprzedaż narodowego dziedzictwa”, znaczenie projektu dla rozwoju badań sowietologicznych jest nie do przecenienia. Wśród obszarów badawczych rozwijanych na podstawie uzyskanej dokumentacji źródłowej można wymienić następujące: mechanizmy władzy w ZSRR, Nowa Polityka Ekonomiczna (NEP), historia GUŁagu, wpływ polityki stalinizmu na demografię w Związku Sowieckim, polityka wyznaniowa, polityka zagraniczna i in.

W ciagu ostatnich 20 lat na podstawie tych dokumentów powstały zarówno drobniejsze prace ${ }^{25}$, jak i fundamentalne projekty, z których bodajże najbardziej spektakularnym pod względem uzyskanych wyników i wprowadzonych do obiegu naukowego dokumentów był projekt edycji źródeł „Historia stalinowskiego GUŁAG-u”, realizowany we współpracy Instytutu Hoovera z GARF w latach 1998-2005 ${ }^{26}$. Inny program badawczy zrzeszający badaczy sowieckiego modelu ekonomicznego, na czele z profesorem ekonomii Uniwersytetu w Houston Paulem Gregory'em, zaowocował wieloma cennymi opracowaniami, które na podstawie materiału źródłowego usystematyzowały dotychczasową wiedzę na temat stalinowskiego modelu gospodarki ${ }^{27}$. Z kolei amerykańsko-polska dziennikarka i członkini kolegium redakcyjnego „The Washington Post", Anne Applebaum otrzymała w 2004 r. Nagrodę Pulitzera za wydaną w 2003 książkę o GUŁagu ${ }^{28}$, która powstała również dzięki materiałom sowieckiej proweniencji z Archiwum Hoovera.

Analizę posowieckich materiałów rozpocząć należy od obszernego zespołu „Archives of the Soviet communist party and Soviet state microfilm collection”. Najliczniejszą i najobszerniejszą grupę dokumentów w ramach kolekcji tworzą akta GARF, które zamierzam omówić nieco bardziej szczegółowo.

${ }^{24}$ Masowe rozkradanie majątku państwowego na tle powstania nowego systemu władzy w Rosji szczegółowo przeanalizował w swojej pracy Włodzimierz Marciniak. Zob. idem, Rozgrabione Imperium. Upadek Zwiazku Sowieckiego i powstanie Federacji Rosyjskiej, Kraków 2001.

${ }^{25}$ Zob. Russia and the Soviet Union at the Hoover Institution Library. A Bibliography of Materials Published or Sponsored by the Hoover Institution on War, Revolution and Peace, wyd. M. Molloy, Palo Alto 2005.

${ }^{26}$ История сталинского Гулага. Конеи 1920-х - первая половина 1950-х годов. Собрание документов в 7 толах, редакционный совет издания Ю.Н. Афанасьев [i in.], Москва 2004-2005.

${ }^{27}$ Zob. P. Gregory, Behind the Façade of Stalin's Command System, Stanford 2001; idem, The Political Economy of Stalinism. Evidence from the Soviet Secret Archives, Cambridge 2004; O. Khlevnyuk, The Economy of the GPU, NKVD, and MVD of the USSR, 1930-1953. Scale, Structure and Trends of Development, w: The Economics of Forced Labor. The Soviet Gulag, red. P. Gregory, V. Lazarev, Stanford 2004.

${ }^{28}$ A. Applebaum, Gulag. A History, New York 2003. Polskie tłumaczenie ukazało się w 2005 r. Gułag, tłum. J. Urbański, tłum. rozdz. 1 M. Claire Wybieralska, Warszawa 2005. 
Zacznę od zespołu (фонд P393) NKWD RFSRR (lata 1917-1930). Archiwum Hoovera nie dysponuje kopiami wszystkich dokumentów, a tylko wybranych fragmentów. Łącznie materiały tego zespołu obejmuja 21816 dokumentów z inwentarzy (описи) $\mathrm{nr}$ 1, 1A, 2-18, 18A, 19-23, 23A, 24-43, 43A, 44-84 oraz $87-91^{29}$. Niestety angielskojęzyczne opisy akt mają bardzo skrótowy i niepełny charakter ${ }^{30}$, zatem dla lepszego ich wykorzystania należy sięgnąć do rosyjskojęzycznego informatora o zasobach archiwalnych GARF ${ }^{31}$ lub rozbudowanych opisów zawartości zespołów dostępnych również w wersji elektronicznej na stronie internetowej rzeczonego archiwum ${ }^{32}$.

Ludowy Komisariat Spraw Wewnętrznych utworzony został 26 X 1917 r. jako jeden z pierwszych urzędów powołanych w ramach Rady Komisarzy Ludowych Sowieckiej Rosji. Powstała niecałe dwa miesiące później w grudniu 1917 r. Czeka ${ }^{33}$ przejęła funkcje walki z przeciwnikami politycznymi bolszewików. I chociaż Czeka nie wchodziła formalnie w skład NKWD, to jej przewodniczący, Feliks Dzierżyński, był początkowo członkiem Kolegium NKWD, a od 1919 r. łączył funkcje przewodniczącego Czeki i szefa NKWD. Po utworzeniu w 1922 r. Państwowego Zarządu Politycznego (GPU) przy NKWD RFSRR połączono obydwa urzędy, a następnie w 1923 r. po przekształceniu GPU w Zjednoczony Państwowy Zarząd Polityczny (OGPU) aż do końca 1930 r. NKWD RFSRR podlegał Radzie Komisarzy Ludowych i nie pełnił funkcji policji politycznej.

Dodać warto, że nawet po utworzeniu 30 XII 1922 r. Związku Socjalistycznych Republik Rad NKWD RFSRR nadal realizował zadania w skali ogólnozwiazkowej, nadzorując nadawanie i odbieranie obywatelstwa sowieckiego, działalność Kościołów, w tym rzymskokatolickiego, organizacje obozów pracy itd. Komisariaty spraw wewnętrznych poszczególnych republik związkowych, a więc Białoruskiej SRR, Ukraińskiej SRR czy Zakaukaskiej FSRR ${ }^{34}$ oprócz

${ }^{29}$ Cyt. za: L. Soroka, Guide to the Archives of the Soviet communist party and Soviet state microfilm collection: State Archives of the Russian Federation, http://www.oac.cdlib.org/ findaid/ark:/13030/kt0779r3rv/?query=GARF (dostęp: 30 X 2018).

${ }^{30}$ Zob. Archives of the Soviet Communist Party and Soviet State. Catalogue of Finding Aids and Documents, Cambridge 1995.

${ }^{31}$ Por. Перечень фбондов Государственного архива Российской Федерации и научно-справочньй аппарат к докулентал архива, ред. С.В. Мироненко, Государственньий архив Российской Федерации. Путеводитель, т. VI, Москва 1998.

${ }^{32}$ Zob. Электронные описи. Ф. Р393. Народный комиссариат внутренних дел РСФСР (НКВД РСФСР), http://statearchive.ru/383 (dostęp: 30 X 2018).

${ }^{33}$ Czeka (potocznie), właściwie WCzk - Wszechrosyjska Komisja Nadzwyczajna do Walki z Kontrrewolucją i Sabotażem przy Radzie Komisarzy Ludowych RSFRR (ros. Всероссийская чрезвычайная комиссия по борьбе с контрреволюцией и саботажем при Совете народных комиссаров РСФСР).

${ }^{34}$ Zakaukaska Federacyjna Socjalistyczna Republika Sowiecka - jedna z czterech republik federacyjnych ZSRR istniejąca w latach 1922-1936 i łącząca Armeńską SRR, Azerbejdżańską SRR i Gruzińską SRR. 
partyjnych władz republikańskich podlegały NKWD RFSRR, co skutkowało kierowaniem wszelkiego rodzaju sprawozdawczości do Moskwy. Natomiast NKWD ZSRR jako centralny ogólnozwiązkowy organ powstał dopiero w 1934 r. po połączeniu w ramach jednego resortu funkcji ochrony porządku publicznego, policji politycznej oraz służb specjalnych (wywiadu i kontrwywiadu).

Omówienie zawartości aktowej całego zespołu wykraczałoby poza ramy tego artykułu. Wśród typowej dla tego rodzaju instytucji dokumentacji znajduja się materiały związane z zarządzaniem milicja, ochrona kolei, fabryk i zakładów pracy, ewidencją ludności i rejestracją aktów stanu cywilnego. Do centralnego aparatu NKWD wpływały uchwały KC RKP(b)/WKP(b) ${ }^{35}$, Rady Pracy i Obrony ${ }^{36}$, WRRR ${ }^{37}$, korespondencja z Czeka, GPU, poszczególnymi resortami, m.in. Narkomnacem ${ }^{38}$. Dokumenty te daja przekrojowy obraz zmian zachodzących w Rosji sowieckiej i ZSRR i nowej polityki narodowościowej, tzw. autochtonizacji, z czego zrodził się eksperyment polski - utworzenie w nadgranicznych rejonach Białorusi i Ukrainy polskich autonomicznych jednostek - Marchlewszczyzny i Dzierżyńszczyzny.

Zespół zawiera również obszerną dokumentację związaną z akcją ewakuacji i repatriacji Polaków do kraju, która trwała od 1921 do 1924 r. na mocy postanowień traktatu ryskiego. Sa to zarówno protokoły posiedzeń Delegacji Rosyjskiej Komisji Mieszanej ds. Repatriacji, jak i listy wraz z ankietami (w porządku alfabetycznym) osób ubiegających się o wyjazd do Polski. Szczególne znaczenie mają tu ankiety Polaków, gdzie znajdujemy informacje biograficzne, dane zwiazane z wykonywaniem zawodu itd. Odrębne zagadnienie stanowią dokumenty dotyczace działalności Polskiego Biura RKP(b) powołanego w lipcu 1919 r. wśród ludności polskiej w Rosji, ale także wśród polskich jeńców wojennych, których planowano wykorzystać dla planów eksportu rewolucji3i ${ }^{39}$.

${ }^{35}$ Rosyjska Partia Komunistyczna (bolszewików) wywodzi się z frakcji bolszewickiej Socjaldemokratycznej Partii Robotniczej Rosji i pod taką nazwą występowała w latach 1918-1925. W grudniu 1925 r. podczas XIV zjazdu nazwa partii zmieniła się na Wszechzwiązkowa Komunistyczną Partię (bolszewików).

${ }^{36}$ Rada Pracy i Obrony (ros. Совет Труда и Обороны - CTO) - nadzwyczajny organ władzy RFSRR, utworzony w 1920 r. w czasie domowej w Rosji, który funkcjonował do 1937 r. Do głównych zadań Rady należało zarządzanie gospodarką i obroną kraju.

37 Wojskowa Rada Rewolucyjna Republiki (ros. Революционный Военный Совет Республики - PBCP) - nadzwyczajny organ władzy polityczno-wojskowej Rosji sowieckiej, powstały w 1918 r. w celu realizacji administracyjnego i operacyjnego kierownictwa siłami zbrojnymi RFSRR. Rada została zlikwidowana w $1934 \mathrm{r}$.

38 Narkomnac (ros. Наркомнац) - Ludowy Komisariat ds. Narodowości (Народный комиссариат по делам национальностей), komisariat ludowy (ministerstwo) nadzorujacy sprawy narodowościowe w Rosji sowieckiej. Stanowisko ludowego komisarza (ministra) zajmował w latach 1917-1924 Stalin. Wykaz dokumentów (protokołów) Narkomnacu zob. Протокольь руководящи органов Народного колиссариата по делал национальностей РСФСР 1918-1924 гг. Каталог документов, ред. В.П. Козлов, Москва 2001.

${ }^{39} \mathrm{O}$ działalności Polskiego Biura Agitacji i Propagandy KC RKP(b) i szerzej polskich komunistów w Rosji sowieckiej w latach 1918-1922 pisał Konrad Zieliński, bazując głównie na 
Jako jeden z dowodów na wartościowy charakter zawartości zespołu dla badań nad historią Polaków w ZSRR podam następujący przykład. W materiałach Centralnego Zarządu Administracyjnego NKWD RSFRR (Центральное административное управление) w aktach Tajnego Wydziału (Секретный отдел) przechowywane sa kompletne materiały dotyczące funkcjonujących na obszarze całego Związku Sowieckiego kościołów, wykazy księży i komitetów kościelnych oraz listy najbardziej aktywnych wiernych. Dane te gromadzono na poziomie republik związkowych oraz gubernialnych wydziałów NKWD, a następnie przesyłano do centrali. Jeden z takich raportów, wedle stanu z 15 VIII 1924 r. (a więc po zakończeniu akcji repatriacyjnej) liczaccy ponad 240 stron, został sporządzony na wniosek Zofii Dzierżyńskiej, sekretarza Polskiego Biura Agitacji i Propagandy KC RKP(b) ${ }^{40}$. Można przypuszczać, że większość ludzi znajdujących się na celowniku NKWD w niedalekiej już przyszłości zginie w rozkręcającej się machinie terroru.

Wśród innych zespołów GARF związanych tematycznie z represyjna polityka państwa bolszewickiego, działalnością sądów, prokuratury należy wymienić następujące: Naczelny Trybunał przy Wszechrosyjskim Centralnym Komitecie Wykonawczym oraz Naczelny Sąd RSFRR (фонд P-1005), m.in. akta Kolegium Wojskowego (lata 1921-1923) ${ }^{41}$; Główny Zarząd Miejsc Odosobnienia NKWD (фонд P-4042) gromadzacy dokumentacje z lat 19221930 o systemie sowieckich obozów, będących zalążkiem GUŁagu ${ }^{42}$; Prokuratura ZSRR (фонд P-8131), wybrane akta od 1924 do 1980 r.; Sąd Najwyższy ZSRR (фонд P-9474), lata 1923-1991; Ludowy Komisariat Sprawiedliwości ZSRR (фонд P-9492), lata 1936-1946; IV Wydział Specjalny Ministerstwa Spraw Wewnętrznych (MSW) (фонд P-9479) zajmujacy się tzw. specprzesiedleńcami, a więc także zesłańcami polskimi (lata 1930-1956) ${ }^{43}$.

materiałach RGASPI. Zob. idem, Działalność Polskiego Biura Agitacji i Propagandy KC RKP[b] wśród jeńców-Polaków w latach 1918-1922, „Res Historica” 2011, nr 32, s. 37-55; idem, O Polska Republikę Rad. Dziatalność polskich komunistów w Rosji Radzieckiej 1918-1922, Lublin 2013.

${ }^{40}$ Archiwum Hoovera, GARF, f. 393, op. 1a, d. 164. Korespondencja NKWD RSFRR z KC RKP(b) w sprawie liczby kościołów, księży, komitetów kościelnych i innych ośrodków katolickich na terytorium ZSRR.

${ }^{41}$ Ros. Верховный Трибунал при Всероссийском центральном исполнительным комитете; Верховный Суд РСФСР. Rewolucyjne trybunały tworzone na szczeblu gubernialnym i w dużych miastach były nadzwyczajnym organem sądowym. Funkcjonowały w Rosji sowieckiej i innych republikach sowieckich w latach 1918-1923 i stanowiły obok Czeka jedno z narzędzi do zwalczania przeciwników politycznych bolszewików w ramach „czerwonego terroru".

${ }^{42}$ Ros. Главное управление местами заключения (ГУМЗ) НКВД.

${ }_{43}$ Ros. 4-й Спецотдел МВД. Specprzesiedleniec to szczególna kategoria obywatela w sowieckim systemie represyjnym, przesiedlonego przymusowo ze stałego miejsca zamieszkania do odległych części ZSRR bez wypełniania jakichkolwiek sądowych formalności. Wiązało się to z ograniczeniem wolności osobistej, m.in. swobodnego poruszania się itd. Na początku lat trzydziestych do tej kategorii najczęściej trafiały rodziny kułaków, a w okresie „Wielkiego 
Także zespół Rady Komisarzy Ludowych (фонд P-5446), gromadzący materiały z okresu 1922-1958, zawiera obszerną dokumentacją dotyczaca działalności rządu sowieckiego, dublującego niejako decyzję KC WKP(b) w zakresie spraw związanych z represyjna polityka. Znajdziemy tutaj zarządzenia odnoszace się do utworzenia przymusowych obozów pracy, korespondencję z GPU/OGPU, zaostrzenia przepisów prawa itd. Wymieniony powyżej zespół w miejscu stałego przechowywania w Moskwie liczy 162 inwentarze, z czego Archiwum Hoovera dysponuje kopiami akt z niepełnych 46 inwentarzy. Warto podkreślić ich nadzwyczaj obszerny rozmiarowo charakter, bowiem jeden inwentarz liczyć może przeszło kilka tysięcy jednostek archiwalnych. Pozyskane przez Amerykanów z zasobów GARF ponad 3 mln klatek mikrofilmu dokumentów w ramach projektu do historii GUŁagu niewątpliwie stanowia cenne źródło także do historii Polaków w Związku Sowieckim.

Kolejna, skromniejszą ilościowo w porównaniu z poprzednio omawiana grupa dokumentów w ramach „Archives of the Soviet communist party and Soviet state microfilm collection", tworzą akta RGASPI. Najbardziej obszerny jest zespół KC KPZR (бонд 17), który w miejscu stałego przechowywania w Moskwie składa się z 162 inwentarzy ${ }^{44}$, obejmujących dokumenty organów kolegialnych KC - Plenów, Biura Politycznego, Sekretariatu oraz wydziałów, zarządów, komisji itd. Archiwum Hoovera dysponuje kopiami dokumentów 12 inwentarzy przechowywanych na 2457 rolkach $^{45}$. Sa to inwentarze (оnисu) nr 1, 2, 7-9, 75-77, 79, 86, 109 i 139.

Ciekawe pod katem badań bolszewickiej polityki narodowościowej moga być materiały plenów KC RKP(b)/WKP(b) z lat 1918-1941 (onucb 2), Wydziału Statystycznego, Biura Ewidencji i Statystyki oraz Wszechrosyjskiego Spisu Członków RKP(b) (onucь 7, 8, 9), ukazujące zmiany składu kadrowego partii pod katem narodowościowym.

Z kolei Biuro Sekretariatu KC (onucb 86), które pierwotnie realizowało funkcje pomocnicze mające na celu okazywanie wsparcia technicznego dla funkcjonowania Biura Politycznego, Biura Organizacyjnego i Sekretariatu, po wybraniu Józefa Stalina na stanowisko sekretarza generalnego partii zwiększyło znaczenie jako organ polityczny. Cechą charakterystyczną materiałów Biura jest nadzwyczaj szeroki zakres prowadzonych spraw. Znajdujemy tu sprawozdania i różne materiały z prac Komisji Mieszanej ds. Repatriacji,

Terroru” 1937-1938 wysiedleni w ramach „operacji narodowościowych” NKWD, w tym operacji polskiej.

${ }^{44}$ Szerzej na ten temat zob. Российский государственный архив социально-политической истории: путеводитель по фбондал и коллекииял докулентов КПСС (25 октября (7 ноября) 1917 - август 1991 гг.). Справочно-инбборлационные материалы к документальнымм и музейным фбондам РГАСПИ, Вып. 4, Москва 2008.

${ }^{45}$ L. Soroka, Guide to the Archives of the Soviet communist party and Soviet state microfilm collection: Russian State Archives of Social and Political History (Rossiiskii gosudarstvennyi arkhiv sotsialno-politicheskoi istorii - RGASPI), http://pdf.oac.cdlib.org/pdf/hoover/fond17. pdf (dostęp: 10 XII 2018). 
korespondencję Ambasady RP w Moskwie z sowieckimi urzędami z lat dwudziestych czy sprawozdania Czeka o sytuacji na pograniczu polsko-sowieckim i prowadzonej pracy wywiadowczej.

Warte odnotowania sa dokumenty z inwentarza 109 pod nazwą „Zbiór Dokumentów ds. Obrony Republiki Sowieckiej i Budowy Wojska"46. Znajdujemy tu dokumentację z okresu pierwszych lat rewolucji i wojny domowej w Rosji, do historii wojny polsko-bolszewickiej, działalności Stalina jako komisarza Frontu Południowo-Zachodniego, materiały o próbach tworzenia z polskich jeńców czerwonych oddziałów na jesieni 1920 r. i in.

Resztę dokumentacji RGASPI dostępnej w Archiwum Hoovera tworzy 38 zespołów (nr 34-59, 337, 447, 572, 582, 586, 592, 593, 604, 620, 628, 646), zawierających przeważnie jeden, maksymalnie dwa inwentarze dostępne na 261 rolkach. Składają się na nie m.in. materiały Zjazdów Socjaldemokratycznej Partii Robotniczej Rosji (RSDRP)/RKP(b)/WKP(b)/KPZR (II-XIX, XXIII-XXVIII, lata 1903-1990), konferencji RKP(b) (V-XVI, lata 1908-1929). Ocenzurowane protokoły, stenogramy zjazdów były publikowane przez Komisję ds. Historii Rewolucji Październikowej (Hispart), następnie w latach pięćdziesiątych w serii „KPZR w stenogramach dokumentach, materiałach”. W ciagu ostatnich dwóch dekad nakładem wydawnictwa „Rospen” ukazały się niepublikowane w czasach sowieckich dokumenty, jak chociażby materiały praskiej (bolszewickiej) i wiedeńskiej (mienszewickiej) konferencji RSDRP, która odbyła się w 1912 r.

Ostatnia, najmniejsza grupę dokumentów z zasobu „Archives of the Soviet communist party and Soviet state microfilm collection" tworzą akta RGANI. Sa to materiały dwóch zespołów: fond 6 (Komisja Partyjnej Kontroli (KPK) przy KC WKP(b), 1934-1966) zawierajacy 6 inwentarzy zmikrofilmowanych na 972 rolkach oraz fond 89 (Proces Komunistycznej Partii Związku Sowieckiego, 1918-1992). Od 1934 r. funkcjonowały dwa organy kontroli na szczeblu władz centralnych: rzeczona KPK przy KC WKP(b), czuwająca nad postawą ideologiczną i etyczną członków WKP(b) oraz Komisja Kontroli Sowieckiej (państwowej) przy Radzie Komisarzy Ludowych ZSRR. W aktach KPK znajdujemy sprawozdania Plenum, Biura, partyjnych „trójek”, dotyczące głównie spraw zwiąanych z postępowaniami wszczętymi wobec członków partii. Obok spraw odnoszących się do naruszenia dyscypliny finansowej, łamania dyscypliny partyjnej, szczególnie ciekawe mogą być materiały z lat 1936-1939, dotyczace represjonowanych i wydalonych z partii członków, m.in. w trakcie „Operacji polskiej NKWD”.

Ostatni zespół z zasobów RGANI obejmuje łącznie 76 inwentarzy z ponad 3 tys. dokumentów. Materiały te przechowywane są na 24 rolkach $^{47}$. Ze względu

${ }^{46}$ Ros. „Коллекция документов по вопросам обороны Советской республики и военного строительства”.

47 Szerzej na ten temat zob. wprowadzenie w: Communist Party of the Soviet Union on trial. Fond 89: archives of the Communist Party and Soviet state. Guide to the microfilm collection in the Hoover Institution Archives, wyd. L. Soroka, Stanford 2001. 
na nietypowy charakter tego zespołu sprawę jego powstania warto bardziej obszernie omówić.

Fond 89 powstał niejako przy okazji sprawy z 1992 r., która toczyła się w Sądzie Konstytucyjnym Federacji Rosyjskiej i dotyczyła zbadania zgodności z konstytucją dekretów prezydenta Jelcyna o zawieszeniu działalności KPZR oraz komunistycznej partii RSFRR, a także o przejęciu tytułów prawnych do majątku partii. Formalnie sprawa została zgłoszona przez grupę 37 deputowanych Zjazdu Deputowanych Ludowych RSFRR (po 1992 r. FR), najwyższego organu ustawodawczego Rosji w latach 1990-1993. Jeden z dekretów Jelcyna zawierał dyspozycję wydaną ministrowi spraw wewnętrznych przeprowadzenia dochodzenia w sprawie „antykonstytucyjnej działalności partii komunistycznej”.

W maju 1992 r. została powołana Specjalna Komisja ds. Archiwów przy Prezydencie FR, której celem było odtajnienie materiałów archiwalnych na potrzeby procesu, swego rodzaju nowej Norymbergi ${ }^{48}$. Innymi słowy, w walce politycznej toczonej przez „reformatora” Jelcyna z „betonem” partyjnym istotna rolę miały odegrać dokumenty archiwalne, ukazujące „niekonstytucyjne" oblicze partii.

Efektem pracy Komisji było odtajnienie dokumentów świadczących o zbrodniach sowieckiego reżimu i odpowiedzialności za nie komunistycznej partii ZSRR. Anatolij Kononow, emerytowany sędzia Sądu Konstytucyjnego (SK), wspominał w jednym z wywiadów: „[...] Były tam materiały o Katyniu, i o tym, jak rozpoczęła się wojna w Afganistanie [...] Ale przewodniczący SK, Walerij Zor'kin powiedział: "I co nam daja te dokumenty? To sa jakieś Zwoje znad Morza Martwego»”. Podobne „lekceważące” zdanie podzielali inni członkowie SK i w efekcie wielu ważnych materiałów archiwalnych nie dołączono do akt śledztwa ${ }^{49}$.

Właśnie w tym czasie do Rosji do udziału w zespole Jelcyna został zaproszony rosyjski dysydent i obrońca praw człowieka, deportowany z ZSRR w 1976 r. Władimir Bukowski, gorący orędownik postawienia partii komunistycznej przed sądem. Bukowski postulował otwarcie archiwów partyjnych, co zbiegło się z zamówieniem politycznym. Kulisy pracy w archiwach zamkniętych dotychczas dla ogółu badaczy rosyjski dysydent opisał w swojej książce, przetłumaczonej również na język polski ${ }^{50}$. Bukowski korzystał z nieznanych wówczas na szeroka skalę w Rosji laptopa oraz ręcznego skanera, wykonując ukradkiem kilka tysięcy kopii. Niebawem dostęp do archiwów został

${ }^{48}$ Zob. Архивы Крелля и Старой площади. Документы по «делу КПСС». Аннотированный справочник документов, представленных в Конституционный суд Российской Федераиии по "делу КПСС», отв. составитель И.И. Кудрявцев, ред. В.П. Козлова, Новосибирск 1995, с. 6.

${ }^{49}$ Cyt. za: Два суда одного человека, https://meduza.io/feature/2018/12/26/dva-suda-odnogo-cheloveka (dostęp: 26 XII 2018).

50 Szerzej na ten temat zob. В. Буковский, Московский процесс, Москва 1996; W. Bukowski, Moskiewski proces. Dysydent w archiwach Kremla, tłum. J. Darczewska i in., Warszawa 1998. 
zablokowany, próba dekomunizacji w Rosji nie powiodła się, ale zdobyte dokumenty Bukowski opublikował na Zachodzie.

Dokumenty zgromadzone w trakcie „sprawy KPZR” połączono w jeden zespół - fond 89 i przekazano do RGANI. Składały się na nie dokumenty pozyskane z byłego Archiwum Wydziału Ogólnego KC KPZR, Archiwum Biura Politycznego KC KPZR, Centralnego Archiwum KGB, Archiwum Polityki Zagranicznej ZSRR, Archiwum Rady Najwyższej ZSRR, Centralnego Archiwum Partyjnego Instytutu Marksizmu-Leninizmu przy KC KPZR oraz Centralnego Państwowego Archiwum Rewolucji Październikowej, Wyższych Organów Władzy Państwowej i Administracji ZSRR. Materiały proweniencji partyjnej stanowiły głównie dokumenty (protokoły, wyciagi z protokołów) Politbiura, Sekretariatu oraz notatki wydziałów KC przeważnie za okres powojenny ${ }^{51}$.

Akta te tworzą swego rodzaju „wisienkę na torcie” piramidy władzy partyjnej w ZSRR. Wartość tych dokumentów polega m.in. na tym, że ukazuja tajniki procesu podejmowania decyzji na najwyższych szczeblach i dowodzą odpowiedzialności partii komunistycznej za wszelkiego rodzaju nadużycia, represje i masowe zbrodnie dokonane w ciagu ponad 70 lat sprawowania władzy. Znajdujemy tutaj dokumenty zwiąane ze zwalczaniem religii (opis 24), polityką narodowościową w latach dwudziestych, dokumenty dotyczące działalności Rady Mniejszości Narodowych (opis 52), materiały dotyczące terroru z lat 1937-1938, w szczególności operacji niemieckiej (opis 60) czy materiały tzw. osoboj papki dokumentujące zbrodnię katyńską (opis 14).

Kończąc opis materiałów proweniencji sowieckiej z zespołu „Archives of the Soviet communist party and Soviet state microfilm collection", należy podkreślić, że Instytut Hoovera nie jest wyłącznym dysponentem kopii tych dokumentów na terenie USA i Europy. Część materiałów została przekazana w ramach współpracy innym instytucjom naukowo-badawczym, by wspomnieć chociażby Bibliotekę Kongresu USA, Uniwersytet Harvarda, Uniwersytet Johnsa Hopkinsa, Uniwersytet Melbourne w Australii, Uniwersytet w Glasgow w Wielkiej Brytanii czy Uniwersytet Hokkaido w Japonii.

Warto także zwrócić uwagę na klarowne zasady udostępnienia w Archiwum Hoovera opisanych wyżej materiałów, znacznie różniące się od rzeczywistości panującej w archiwach postsowieckich. Prowadzę regularne badania w archiwach postsowieckich (Litwa, Białoruś, Rosja) od 20 lat i dobrze znam panujące tam realia. Oczywiście obecnie warunki pracy znacząco odbiegaja od tych, które istniały w okresie ZSRR, gdy badacze nie dostawali do rąk ewidencji archiwalnej, a jedynie podawali temat wyznaczonemu przez dyrekcję archiwum opiekunowi. Następnie trzeba było czekać kilka dni, aż archiwista dobierze akta do wskazanego tematu. Dzisiaj zasady pracy w czytelni archiwów rosyjskich sa mniej rygorystyczne, aczkolwiek dla badacza z zagranicy moga stanowić nie lada wyzwanie.

${ }^{51}$ Архивы Крелля..., с. 6. 
Z kolei minimum biurokratycznych wymagań podczas rejestracji w Archiwum Hoovera, sprawne realizowanie zamówień, nowoczesny sprzęt, nieskrępowane możliwości robienia kopii i co najważniejsze, miła i fachowa obsługa daja podstawy do twierdzenia, że instytucja ta może być stawiana za wzór. Czytelne i pozbawione biurokracji zasady korzystania z dokumentów w czytelni Archiwum Hoovera zachęcają do odwiedzania tej placówki również przez zagranicznych sowietologów.

O tym, że kwerenda w Archiwum Hoovera może być bardziej efektywna i paradoksalnie opłacalna z punktu widzenia poniesionych kosztów, przekonuje rosyjski historyk z Instytutu Historii Rosji Rosyjskiej Akademii Nauk, Mikhail Nakonechny, który w 2013 r. podczas dwutygodniowego pobytu w Archiwum Hoovera przeprowadził kwerendę (w zespole MSW GARF). Historyk pochodzący z Sankt Petersburga, badając śmiertelność więźniów w sowieckich obozach, w ciagu zaledwie dwóch tygodni skopiował kilka tysięcy dokumentów bez żadnych oporów ze strony pracowników archiwum i do tego nie zapłacił za to ani grosza. Jak sam przyznał, wykonanie takiej operacji w Rosji wymagałoby czterokrotnego pokonania trasy Sankt-Petersburg-Moskwa, zdobycia szturmem GARF, uzyskania całej masy zezwoleń i pieczątek oraz zapłacenia ponad 2000 USD za kserokopie ${ }^{52}$. Również z ponadpółrocznych obserwacji w czytelni Archiwum Hoovera piszącego niniejsze słowa wynika, że druga co do liczebności grupę badaczy z zagranicy, poza Chińczykami, stanowia właśnie Rosjanie.

Wracajac do tezy postawionej we wstępie artykułu, stwierdzam, że zasoby Archiwum Hoovera pozwalaja na podjęcie badań w obszarze sowieckiej polityki narodowościowej, w tym również wobec Polaków i tzw. kwestii polskiej. Opisane wyżej materiały z zespołu „Archives of the Soviet communist party and Soviet state microfilm collection" przechowywane w Archiwum Hoovera w moim przekonaniu stanowić mogą wartościowe źródło do badań nad losem Polaków w Rosji sowieckiej i ZSRR. Wydaje się, że możliwość taka nie była wykorzystywana przez nieliczne przecież grono polskich badaczy penetrujących głównie federalne archiwa rosyjskie, a na szczeblu poszczególnych postsowieckich republik - archiwa białoruskie oraz ukraińskie (otwarcie po 2014 r. archiwów Służby Bezpieczeństwa Ukrainy zwiększyło atrakcyjność tego kraju dla badaczy okresu sowieckiego).

Materiały przechowywane w Archiwum Hoovera mają zasadnicze znaczenie dla badań historycznych nad dziejami narodu polskiego w XX w., narodu rozumianego jako bardzo pojemna kategoria, nieograniczająca się do grupy osób będących obywatelami polskimi. Dotarcie do dokumentów proweniencji sowieckiej w miejscach ich stałego przechowywania w Moskwie bywa często bardzo trudne i wymaga sporych nakładów czasu i finansów i z tego powodu

${ }_{52}$ М. Наконечный, Отчет о поездке в Гуверовский архив, http://beloedelo.com/actual/ actual/?126 (dostęp: 23 X 2018). 
często są one wykorzystywane fragmentarycznie. Okazuje się bowiem, że mimo odległości dzielącej Warszawę i Palo Alto badaczom historii ZSRR i Europy Wschodniej w XX w. bliżej do Kalifornii, niż do położonej zaledwie tysiąc kilometrów na wschód od Warszawy Moskwy...

\section{Streszczenie}

W artykule omówiono materiały proweniencji sowieckiej przechowywane w Archiwum Hoovera w Kalifornii i dotyczące Polaków w Rosji sowieckiej i ZSRR w dwudziestoleciu międzywojennym. Oryginały dokumentów znajdują się w trzech rosyjskich archiwach: RGANI, RGASPI i GARF. Problem ten rozpatrywany jest na tle procesu pozyskiwania tych dokumentów przez stronę amerykańską w Rosji w latach dziewięćdziesiątych ubiegłego stulecia. Szczególną uwagę autor poświęcił analizie akt instytucji sowieckich, odpowiedzialnych za politykę narodowościową w Rosji sowieckiej i ZSRR. Jak ustalono, akta proweniencji sowieckiej znajdujace się w zasobach Archiwum Hoovera stanowią bogate i mało zbadane przez sowietologów źródło wiedzy na temat losów Polaków w Rosji sowieckiej i ZSRR.

\section{Sources for the History of Poles in Soviet Russia and the USSR in the Interwar Period in the Soviet Collections of the Hoover Archives}

This article draws on Soviet archival documents stored at the Hoover Archive in California and concerning Poles in Soviet Russia and the USSR in the interwar period. The original documents are housed in three Russian archives: The Russian State Archive of Contemporary History (RGANI), the Russian State Archive of Socio-Political History (RGASPI), and the State Archive of the Russian Federation (GARF). The author paid particular attention to the analysis of the documents of Soviet institutions responsible for national policy in Soviet Russia and the USSR. As it was established, the documents of the Soviet provenance constitute wide and underestimated source on the history of Poles in the USSR.

\section{Bibliografia}

Archives of the Soviet Communist Party and Soviet State. Catalogue of Finding Aids and Documents, Cambridge 1995.

Bukowski W., Moskiewski proces. Dysydent w archiwach Kremla, tłum. J. Darczewska i in., Warszawa 1998.

Butcher B., Cracking the Kremlin Files, „Hoover Digest” 1999, nr 4, https://www.hoover.org/ research/cracking-kremlin-files (dostęp: 16 X 2018).

Głębocki H., Fatalna sprawa. Kwestia polska w rosyjskiej myśli politycznej (1856-1866), Kraków 2000.

Libera P., Restytucja archiwaliów francuskich z Archiwum Specjalnego w Moskwie, „Archeion” 2006, t. CIX, s. 131-157.

Marciniak W., Rozgrabione Imperium. Upadek Zwiazku Sowieckiego i powstanie Federacji Rosyjskiej, Kraków 2001.

Siekierski M., Hoover Institution's Polish Collections: An Overview and a Survey of Selected Materials on Polish Soviet Relations, „Polish Review” 1988, t. XXXIII, nr 3, s. $325-341$. 
Siekierski M., Zarys historii polskich zbiorów Biblioteki i Archiwum Instytutu Hoovera $w$ Kalifornii, „Z Badań nad Książką i Księgozbiorami Historycznymi” 2017, tom specjalny, s. 557-566.

Siekierski N., Jan Karski i Instytut Hoovera, „Archeion” 2011, t. CXII, s. 153-160.

Soroka L., Guide to the Archives of the Soviet communist party and Soviet state microfilm collection: State Archives of the Russian Federation, http://www.oac.cdlib.org/findaid/ ark:/13030/kt0779r3rv/?query=GARF (dostęp: 30 X 2018).

Stępniak W., Archiwalia polskie w zbiorach Instytutu Hoovera Uniwersytetu Stanforda, Warszawa 1997.

Stępniak W., Możliwości badawcze historyków polskich na Uniwersytecie Stanforda. Polonika w zbiorach Hoover Institution Archives, „Archeion” 1997, t. XCIVII, s. 112-116.

Winid B., Wspótczesne archiwalia polskie i rosyjskie $w$ zbiorach Instytutu Hoovera [tłum. z j. ang. E. Rosowska], „Archeion” 1995, t. XCV, s. 243-245.

Zasztowt L., Siekierski M., Dwie rosyjskie kolekcje w zbiorach Archiwum Instytutu Hoovera Uniwersytetu Stanforda, „Przegląd Wschodni” 2000, t. VII, z. 1 (25), s. 159-182.

Zieliński K., Działalność Polskiego Biura Agitacji i Propagandy KC RKP[b] wśród jeńców-Polaków w latach 1918-1922, „Res Historica” 2011, nr 32, s. 37-55.

Zieliński K., O Polska Republikę Rad. Działalność polskich komunistów w Rosji Radzieckiej 1918-1922, Lublin 2013.

Архивы Крелля и Старой площади. Документы по "делу КПСС». Аннотированный справочник документов, представленных в Конституиионный суд Российской Федерации по «делу КПСС», отв. составитель И.И. Кудрявцев, ред. В.П. Козлова, Новосибирск 1995.

Горизонтов Л., Парадоксы илперской политики. Поляки в России и русские в Польше, Москва 1999.

Даниельсон Е., Архивы русских элигрантов в Гуверовскол институте, „Вестник архивиста" 2001, № 1, с. 202-211.

История Росархива, http://archives.ru/rosarhiv/history.shtml (dostęp: 16 X 2018).

Козлов В.П., Российские архивы: проблель доступа и использования, „Делопроизводство” 2012, № 1, c. 7-12.

Наконечный М., Отчет о поездке в Гуверовский архив, http://beloedelo.com/actual/ actual/?126 (dostęp: 23 X 2018).

Перечень фбондов Государственного архива Российской Федерации и научно-справочный аппарат к документам архива, ред. С.В. Мироненко, Государственный архив Российской Федерации. Путеводитель, т. VI, Москва 1998.

Пихоя Р.Г., Записки археограбба, Москва 2016.

Jan Szumski - dr hab., profesor nadzwyczajny w Instytucie Historii Nauki Polskiej Akademii Nauk im. A. i L. Birkenmajerów, główny specjalista w Centrali Badań Historycznych Instytutu Pamięci Narodowej, historyk. Zajmuje się tematyką związaną z historią polsko-sowieckich stosunków i kontaktów naukowych oraz dziejami Polaków w ZSRR. E-mail: jszumski@ihnpan.waw.pl.

Jan Szumski - Dr hab., associate professor at the L. \& A. Birkenmajer Institute for the History of Science, Polish Academy of Sciences, chief expert at the Historical Research Office of the Institute of National Remembrance, historian. His research interests cover subjects related to the history of Polish-Soviet scientific relations and contacts as well as the history of Poles in the USSR. E-mail: jszumski@ihnpan.waw.pl. 